\author{
山田＼cjkstart美緒*・杉岡 佳彦・進 博人・大武 義人
}

\title{
Distribution of the Antioxidant Contained in the Vulcanized Rubber and the Rubber Degradation in Tap Water
}

Mio YAMADA ${ }^{1 *}$, Yoshihiko SUGIOKA ${ }^{1}$, Hiroto SHIN $^{1}$ and Yoshito OHTAKE ${ }^{2}{ }^{1}$; INAX CO., LTD., 3-77 Minato-machi, Tokoname, Aichi 479-8588, Japan, ${ }^{2}$; Chemicals Evaluation and Research Institute, Japan, 1600 ShimoTakano, Sugitomachi, Kitakatsushika-gun, Saitama 345-0043, Japan)

The relationship between distribution of antioxidant and degradation of polymer is investigated on EPDM compounded with IPPD that is a typical amine type antioxidant for vulcanized rubber. IPPD in EPDM homogeneously-dispersed by kneading is used. Because of decomposition by heat while molding and volatilization from surface of vulcanized rubber, more IPPD exists inside of rubber than the surface. At the depth of $0 \sim$ about $50 \mu \mathrm{m}$, percolation of water contained with residual chlorine and polymer degradation occur at the same time, IPPD disappears because of its dissolution into the water and consumption by trapping radical generated polymer degradation caused by residual chlorine and heat. In this area the rubber degradation occurs easily, so almost on the surface oxidation degradation progress even though antioxidant exists enough in vulcanized rubber.

(Received on February 10, 2009)

(Accepted on June 8, 2009)

Key Words : Residual Chlorine, Degradation, EPDM, Antioxidant, IPPD, Dissolution, Blooming, Distribution

\section{1. 緒}

\section{言}

水周り製品に使用するパッキン, Oリング，ホースなど の加硫ゴム製品は製品寿命を延ばす目的で他種多様の老化 防止剂が選択，使用されている。これらの老化防止剤は主 に成型加硫時の熱や加硫反応中あるいは使用環境下におけ る劣化因子により消費される．特に水道用パッキンなどの 水に触れる成型品では, 水道水中に含まれる残留塩素や配 管などから溶出した銅イオンなどの金属イオンによる劣化 で老化防止剤は著しく消費され，同時にブルーム等の物理 的現象と相乗して水中へ流出し減少する。老化防止剤が消 失した加硫ゴム製品は, 早期での劣化が生じやすく, 要求 特性が低下し耐用年数を満足できないだけでなく，漏水等 のトラブル発生の諸原因となる。

我々は前報 ${ }^{1)}$ にて水道水使用環境下における老化防止 剤の減少挙動と劣化の関係を明らかにした。すなわち，劣

\footnotetext{
*1株式会社 INAX

（４79-8588 常滑市港町 3-77）

2 財団法人 化学物質評価研究機構

（３45-0043 埼玉県北葛飾郡杉戸町下高野 1600）
}

化処理日数の増加に伴い老化防止剂は減少し, その減少速 度は老化防止剂の種類と分子量で異なり, 減少速度の速い ものはポリマーの劣化も早まることを報告した。つまり, 水道水などの過酷な使用環境下において長期寿命を保つた めには, 老化防止剤の流出を阻止もしくは遅延させ残留塩 素のような劣化因子を長期にわたり無害化することが重要 である. 特に水道水による劣化反応は加硫ゴム成型品の表 面近傍で生じるため, 表面近傍に老化防止剤が多く存在す る傾斜した分布状態が望ましいと考えられる。

本研究では老化防止剤の減少原因や残存した老化防止剤 の深さ方向への分散状態と劣化の関係を明確にするため, 加硫ゴム用として多用され熱老化防止能, オゾン劣化防止 能, 屈曲き裂防止能を兼ね備えたアミン系老化防止剂 $N$ イソプロピル-N'-フェニル-p-フェニレンジアミン (IPPD) $)^{2)}$ を配合したEPDMを用い，水道水中での深さ方向への劣 化状態と老化防止剂の分布の関係を調査した.

\section{2. 実}

験

\section{1 試料}

Table 1 に示すEPDM標準配合 (JIS K6395に準拠)にア 
ミン系老化防止剤(IPPD)を 1 phr添加し，最適加硫条件 にて $2 \mathrm{~mm}$ 厚のゴムシートを作製した。原料の EPDMに は, 三井化学製EPT4045(ジェン含有量 $8 \mathrm{wt} \%$ )を用い, 加硫促進剤には，市販のテトラメチルチウラムジスルフィ ド (TMTD)，2-メルカプトベンゾチアゾール (MBT)を， カーボンブラックには旭カーボン製＃60(FEFブラック), 加硫系は硫黄を使用した。

\section{2 促進劣化処理}

Table 2 に示す水道水を想定した促進劣化処理を実施し た。和光純薬工業製次亜塩素酸ナトリウム溶液にイオン交 換水を加え残留塩素濃度を $200 \mathrm{ppm}$ とし， $\mathrm{HCl}$ を用いて $\mathrm{pH}$ を $6.5 〜 7.0$ に調製後，気密性のあるSchott製ガラス瓶 に試験片と共に封入，静置し，水栓機器などの市場での使 用最高温度領域である $80{ }^{\circ} \mathrm{C}$ に加温した。また，浸せき液 は24時間毎に交換し，できるだけ均一な濃度での処理が 続行するように配慮した。浸せき処理時間は $1 ， 5 ， 10$ ， 15，20日とした。

\section{3 老化防止剤の分布状態および劣化の評価}

老化防止剂含有量は,全体および表面からの深さ毎にそ れぞれ以下のようにして測定した。全体については，処理 後の試験片を室温下の真空乾燥機にて十分に水分を除去 後，試験片全体をロールにて粉砕したものを，試験片の表 面および内部については同試験片を Fortuna 製スプリッテ イングマシーンAN400-D を用い200 $\mu \mathrm{m}$ 毎にスライスした 後に細かく刻んだものを試料に供した。これらをアセトン にて 16 時間ソックスレー抽出し，抽出物を日本電子製ガ スクロマトグラフ質量分析計 (GC/MS) JMS-K9にて定量分 析を実施した。深さ方向に対する酸化劣化状態は，200 $\mathrm{m}$ 毎にスライスした試験片の表面および表面より 200， 400，600，800，1000 $\mu \mathrm{m}$ の位置を顕微 ATR 法にて分析

Table 1 Recipe of the rubber sample

\begin{tabular}{c|c}
\hline \multicolumn{2}{c}{ Standard compound (JIS K6395) + antioxidant } \\
\hline Materials & phr \\
\hline EPDM (Diene content : 8 wt\%) & 100 \\
Stearic acid & 1 \\
CB (FEF) & 80 \\
Paraffin oil & 50 \\
Zinc oxide & 5 \\
Sulfur & 1.5 \\
Accelerator (TMTD) & 1 \\
Accelerator (MBT) & 0.5 \\
Antioxidant (IPPD) & 1 \\
\hline Cure conditions : $160^{\circ} \mathrm{C} \times 20 \mathrm{~min}$ \\
\hline
\end{tabular}

Table 2 Condition of accelerated degradation treatment

\begin{tabular}{l|l}
\hline Immersion fluid & $\begin{array}{l}\text { Chlorine water } \\
\text { (Concentration of residual chlorine : } \\
\text { 200ppm, } \mathrm{pH}: 6.5 \sim 7.0)\end{array}$ \\
\hline Temperature & $80{ }^{\circ} \mathrm{C}$ \\
\hline Times of immersion & $1 \sim 20$ days \\
\hline
\end{tabular}

した。測定にはバイオ・ラッドラボラトリーズ製顕微鏡フ ーリエ変換赤外分光光度計 (FT-IR) FTS-6000を用いた。 劣化断面については，日立製作所製走査型電子顕微鏡 (SEM)S-3400Nを用い加速電圧 $15 \mathrm{kV}$ ，倍率 $\times 1000$ にて断 面観察し, 堀場製作所製エネルギー分散型 X 線分光 $(\mathrm{EDX})$ EX-250を用い断面の元素マッピング分析を実施した。配 合剂の水中への溶出量検討のため，処理 1 日後の浸せき液 中のIPPD，亜鉛 $\mathrm{Zn}$ および硫黄 $\mathrm{S}$ を定量した。IPPDの定 量は浸せき液を $\mathrm{NaOH}$ にて $\mathrm{pH} 10$ とし，塩析でIPPDの溶 解度を下げ，ジクロロメタンにて 2 度抽出し GC/MSにて 分析した。 $Z n$ の定量は容器内壁への吸着防止のため硝酸 を添加し，島津製作所製シーケンシャル型高周波プラズマ 発光分析装置ICPS-8000にて亜鉛イオンを分析したＳＳ 定量はダイオネクス社製イオンクロマトグラフDX-320に て硫酸イオンを定量し，S量に換算した。

\section{3. 結 果 と 考 察}

\section{1 老化防止剂の減少挙動}

促進劣化処理日数に対するゴム試料中の老化防止剤含有 率をFigure 1 に示す。この結果から，加硫ゴムでは処理 日数の増加に伴い老化防止剤含有量が減少するが，特に， 処理 1 日で著しく減少，処理 10 日後には加硫ゴム中の老化 防止剂はほぼ消滅する。一般に，老化防止剤が加硫ゴム中 に存在し，有効に作用している期間(劣化誘導期間)ではポ リマーに対する劣化はほとんど生じず，老化防止剤の消滅 前後付近で, 徐々に劣化が生じ物性低下等の諸現象が現れ ると考えられている ${ }^{3)}$. 今回の結果では加硫ゴム中の老化 防止剂は，処理 5 日で促進劣化処理前の約 $5 \%$ 残存してお り，処理 10 日で完全に消滅することから，劣化や物性低 下は処理 10 日前後で発現すると推測される。しかし，後 述するFT-IRやSEMを用いた劣化状態の分析では，処理 10 日よりも早期に分子構造の変化や表面での劣化反応が 開始されている，老化防止剂が加硫ゴム中に存在するにも 関わらず劣化反応が起きているのは，表面近傍に存在する 老化防止剂が表面での劣化反応により初期に優先的に消費

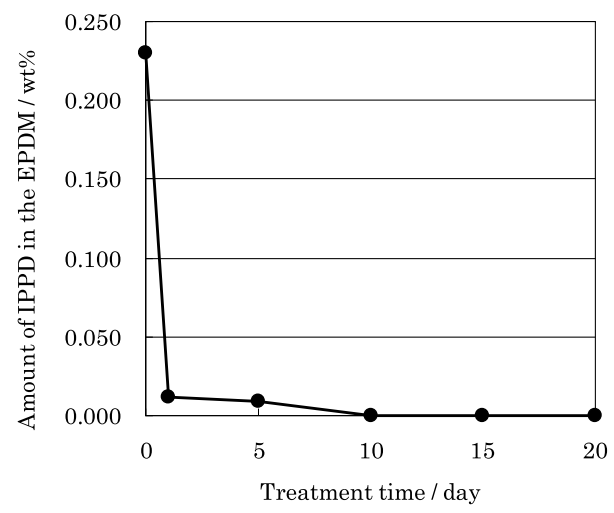

Figure 1 Amount of IPPD in the EPDM to the treatment time. 


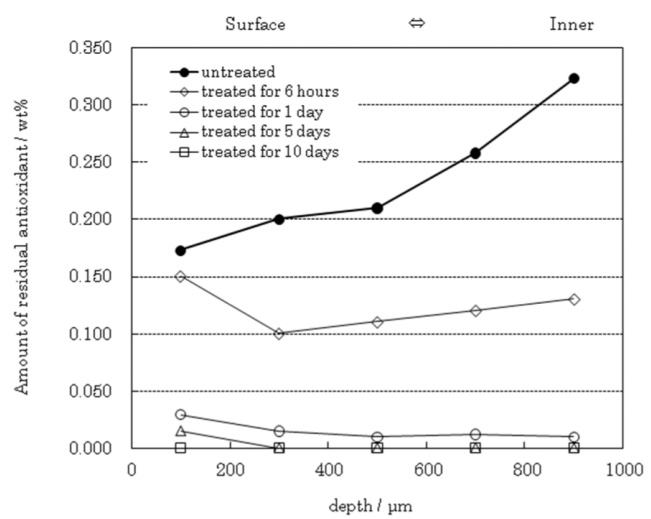

Figure 2 Amount of IPPD in the EPDM every $200 \mu \mathrm{m}$ depth.

されること，また，劣化処理中に加硫ゴム特有のミクロブ ラウン運動、マクロブラウン運動などによる老化防止剂の ゴム内での移動により分布が不均一となり，ゴム表面に老 化防止剤が存在しない，もしくは希薄な状態となり劣化防 止機能を十分には果たしていないと推測されるため, 次項 において老化防止剤の分布状態を検討した。

\section{2 深さ方向の老化防止剤の分布状態}

深さ方向へ厚さ $200 \mu \mathrm{m}$ 毎の老化防止剤の分布状態を Figure 2 に示す．未処理では内部に比べ表面での老化防止 剤含有量が低い。これは, 混練時には十分均一に分散して いた老化防止剤は，プレス成型時や加硫反応時の熱により 表面付近から揮発，消費されたためと考えられる。一方， 処理 1 日, 処理 5 日での老化防止剂含有量は, 内部に比べ 表面近傍の 0 〜 $200 \mu \mathrm{m}$ で多い結果が得られた。これは上 述した処理時の熱によりブルーム現象で老化防止剂が内部 から表面へと移行した結果と考えられる。しかし, 劣化や 溶出現象は表面もしくはその近傍でより激しく生じるため 処理日数の増加に伴い表面近傍で老化防止剂が優先的に消 費されると推察されるため, 次項において表面近傍の劣化 状態を検討した。

\section{3 促進劣化処理における FT-IRを用いたゴム表面お よび内部の劣化状態分析}

促進劣化処理による表面の FT-IR スペクトルを Figure 3 に，表面より $200 \mu \mathrm{m}$ 内部の FT-IR スペクトルを Figure 4 に示す. $1370 \mathrm{~cm}^{-1}$ および $1450 \mathrm{~cm}^{-1}$ 付近の吸収はEPDM ポ リマーのメチル基に由来する。またFigure 3(a)で認めら れる $1540 \mathrm{~cm}^{-1}$ 付近の強い吸収はステアリン酸亜鉛特有の 吸収であり，加硫ゴム表面をキムワイプでふき取ることで 完全に消失することから，滑剤および加硫促進剤として配 合したステアリン酸と $\mathrm{ZnO}$ が反応し生成したステアリン 酸亜鉛がブルームしたものと考えられる. Figure 3のゴム 表面の FT-IR スペクトルでは処理日数の増加に伴い 1710 $\mathrm{cm}^{-1}$ 付近の酸化劣化を示す $\mathrm{C}=\mathrm{O}$ 結合に起因する吸収が増 大する.ゴム表面における酸化劣化開始日数を調べるため, 縦軸に $2900 \mathrm{~cm}^{-1}$ 付近の $\mathrm{C}-\mathrm{H}$ ピーク面積に対する $\mathrm{C}=\mathrm{O}$ ピー
ク面積を，横軸に処理日数をプロットしたグラフを Figure 5 に示す. 処理 5 日で $\mathrm{C}=\mathrm{O}$ 生成が確認されることから 酸化劣化は処理 $1 \sim 5$ 日の間で生じ，処理日数の増加に伴 い進行していく. 一方, 表面より $200 \mu \mathrm{m}$ 内部では $\mathrm{C}=\mathrm{O}$ 結合に起因する吸収が認められず，さらには，この吸収は

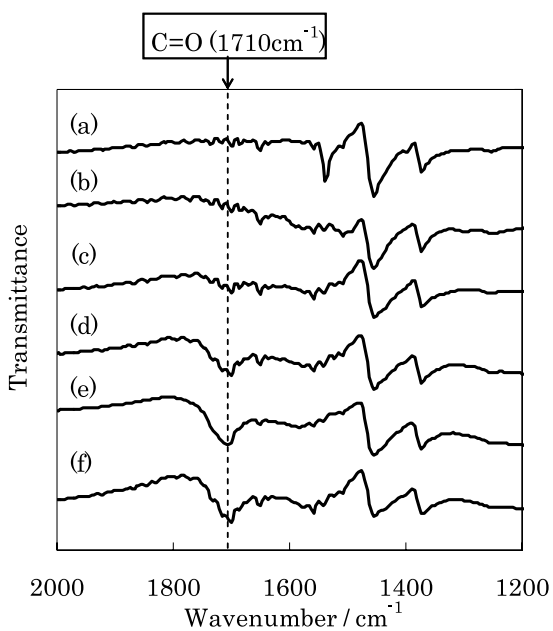

Figure 3 FT-IR spectra on the surface of EPDM: (a) Untreated, (b) Treated for 1 day, (c) Treated for 5 days, (d) Treated for 10 days, (e) Treated for 15 days and (f) Treated for 20 days.

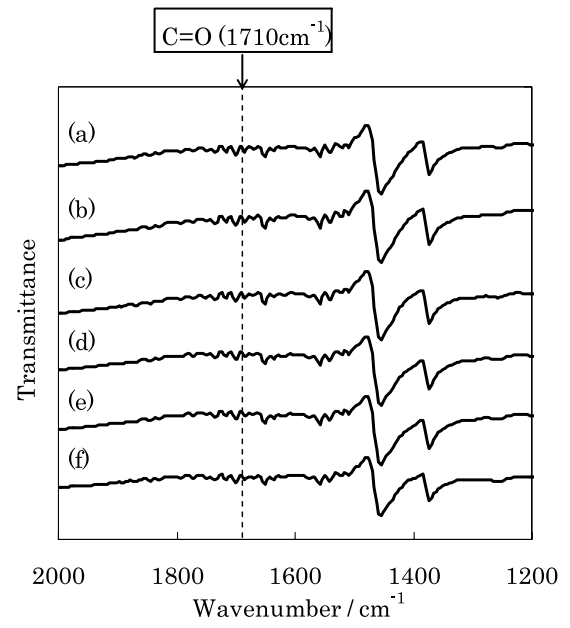

Figure 4 FT-IR spectra in the $200 \mu \mathrm{m}$ depth of EPDM: same in Figure 3 .

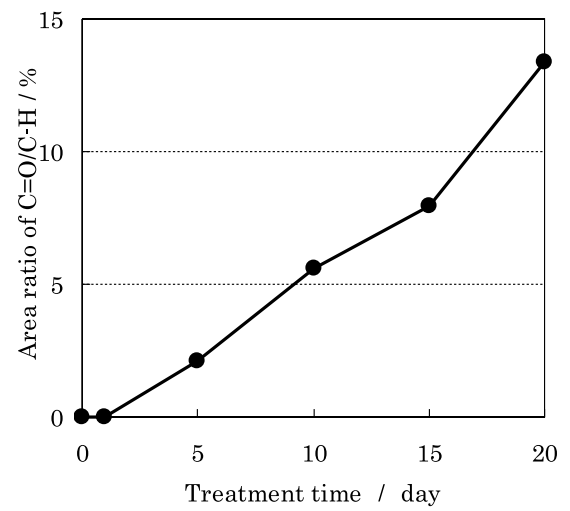

Figure 5 Area ratio of $\mathrm{C}=\mathrm{O} / \mathrm{C}-\mathrm{H}$ at FT-IR spectra on the surface of EPDM plotted against the treatment time. 


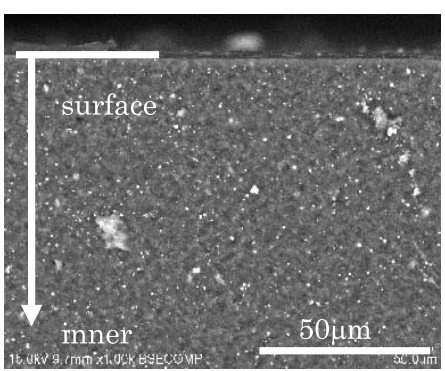

(a) Untreated

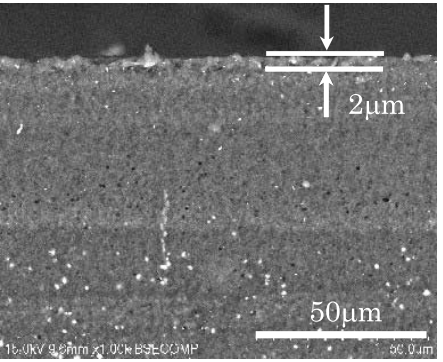

(c) Treated for 5 days

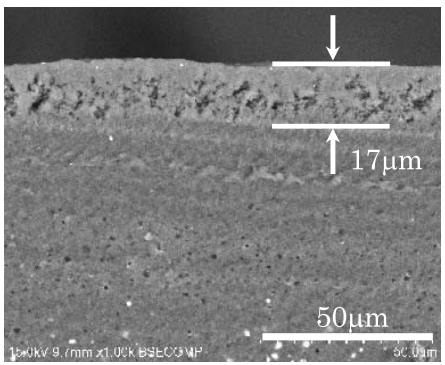

(e) Treated for 15 days

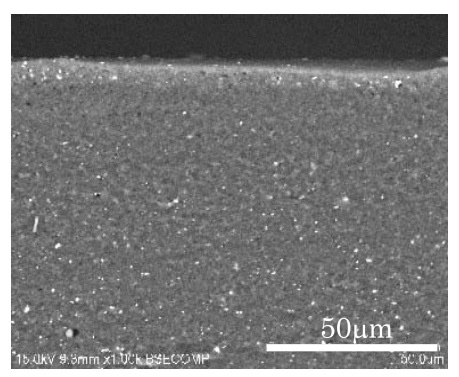

(b) Treated for 1 day

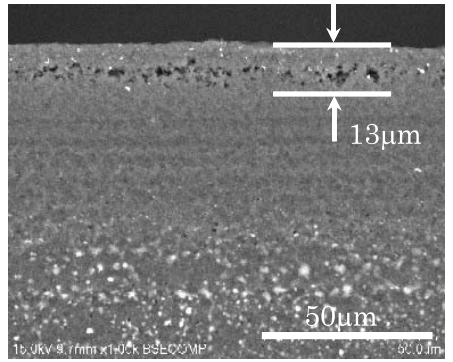

(d) Treated for 10 days

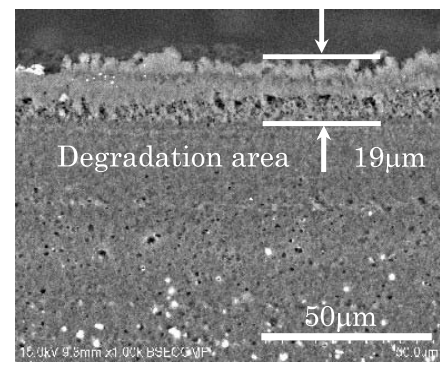

(f) Treated for 20 days
Figure 6 Cross sectional SEM images of EPDM: same in Figure 3.
400, 600, 800, $1000 \mu \mathrm{m}$ の各深さにおいても認められな いことから, 劣化深さは処理日数が増加しても表面から $200 \mu \mathrm{m}$ 以内に限定された範囲内で生じていることが判明 した.

\subsection{SEM による断面の劣化状態の観察}

酸化劣化が生じている表面から $200 \mu \mathrm{m}$ について, SEM にて断面を観察した結果をFigure 6 に示す．処理により 表面では劣化層が生成し, 処理日数の増加に伴い表面から 深さ方向への劣化進行が認められた。前項におけるFT-IR 分析と同様にSEMによる断面観察結果からも処理 5 日で 表面劣化が生じており, その劣化深さは数 $\mu \mathrm{m}$ であった. すなわち，表面の $200 \mu \mathrm{m}$ に老化防止剂が残存しているに も関わらず加硫ゴム最表面の数 $\mu \mathrm{m}$ で酸化劣化が進行し ていた.

\subsection{EDXによる断面の元素マッピング分析}

劣化初期における塩素浸透深さ，および添加剤・配合剂 の分布状態を調査するため, 未処理, 処理 5 日, 処理 10 日後の試験片について EDXを用い断面の元素マッピング を実施した。その結果をFigure 7 に示す。処理 5 日で表 面から約 $50 \mu \mathrm{m}$, 処理 10 日で約 $70 \mu \mathrm{m}$ の深さまで塩素の 存在が認められ, 処理により塩素水が浸透, 吸着したと考 えられる。また同時に塩素水が浸透した領域では配合剤で ある $\mathrm{Zn}$ および $\mathrm{S}$ 濃度が減少していた。これは処理により 加硫ゴム表面から塩素水が浸透した際, 加硫促進助剂とし て配合した $\mathrm{ZnO}$ ，およびステアリン酸と反応し生成した ステアリン酸亜鉛，および加硫剤として配合したSが溶出 (a) Untreated
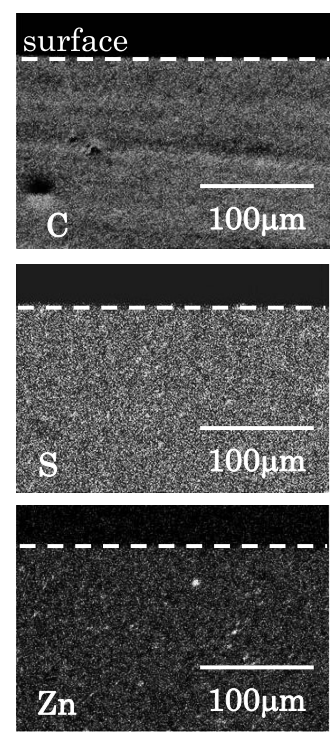

Infiltration area of chlorine water (b) Treated for 5 days

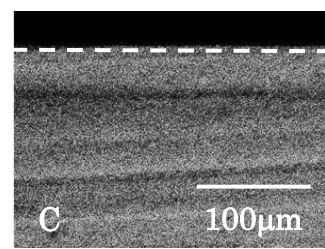

(c) Treated for 10 days
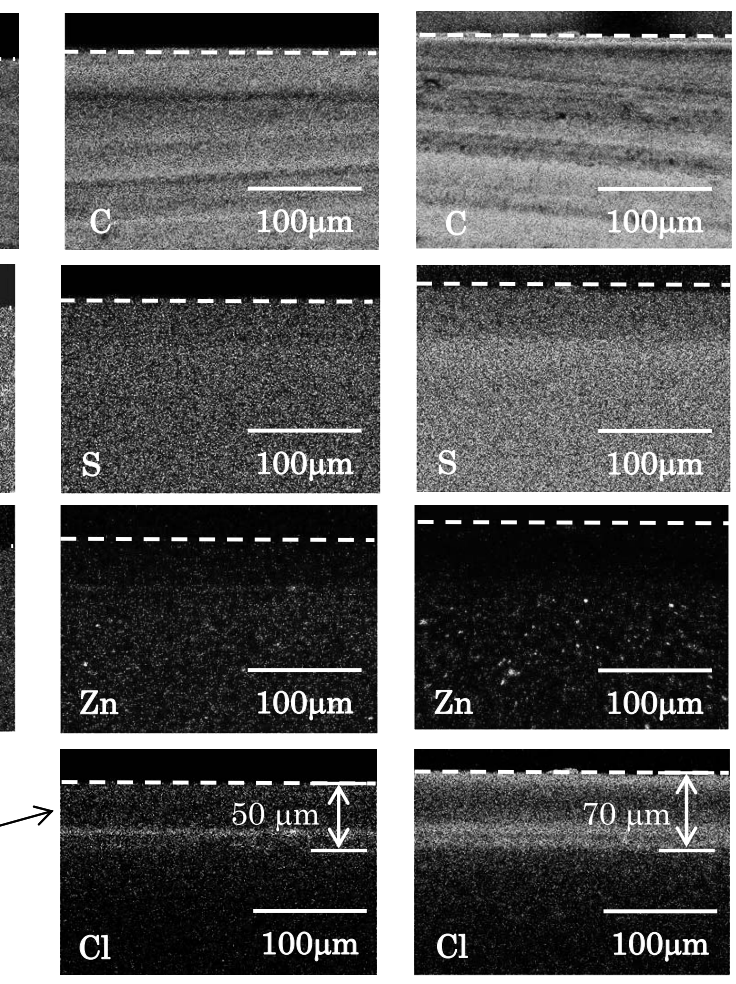

Figure 7 Elemental mapping of C, S, Zn and Cl: (a) Untreated, (b) Treated for 1 day and (c) Treated for 5 days. 
あるいは消費したためと推測される。特に $\mathrm{Zn}$ は塩素と反 応し $\mathrm{ZnCl}_{2}$ を生成すると強い潮解性を示すため溶出現象が 顕著になったものと考えられる。また，ゴムとの相溶性が 比較的低いためにブルームしやすく, さらに水への溶解度 が比較的大きい $\mathrm{IPPD}^{1)}$, 4) は, 塩素水が浸透した領域にて 劣化反応により消費されたばかりでなく溶出現象が促進さ れたと考えられる。

\section{6 老化防止剤・添加剤の溶出と老化防止剂減少原因}

前項において加硫ゴム中の老化防止剤は最表面層より劣 化反応と溶出現象により消費されている可能性が示唆され た. そこで, 水中へのIPPD 溶出量を見積もることで劣化 反応に寄与した老化防止剤量を調査し，さらに，添加剤の 溶出を再確認するため, 処理 1 日後の浸せき液について IPPD，Znおよび Sの定量を実施した。結果をTable 3 に 示す。浸せき液から $\mathrm{Zn}, \mathrm{S}$ おび゙IPPDが検出され，水中 へ添加剤が溶出したことが確認された。さらに，浸せき液 中の IPPD 濃度から，溶出により減少した加硫ゴム中の老 化防止剂量を算出すると $0.043 \mathrm{wt} \%$ あ゙あり, 処理前の老化 防止剂含有量 $0.240 \mathrm{wt} \%$ のちおよそ $1 / 5$ の $0.043 \mathrm{wt} \%$ が 処理 1 日で浸せき液中に溶出したと考えられる。そこで未 加硫ゴム，処理前の加硫ゴム，処理後の加硫ゴムにおける 老化防止剂量および各要因による老化防止剤消費率を示し たグラフを Figure 8 に示す。処理により初期配合量の少 なくとも約 $10 \%$ が溶出により減少，約 $40 \%$ が溶液中の残 留塩素や熱による劣化により生成したラジカルを捕捉する 老化防止剤本来の老化防止機能のために消費されたと考え られる．実際には老化防止剂は溶出後に水中の残留塩素や 熱などにより消費されるため，検出值よりも多く溶出した 可能性がある．また，未加硫ゴムから処理前の加硫ゴムに おける約 $47 \%$ 老化防止剤の減少は混練や加工成型時に おける消費，すなわち，混練のせん断力や 飛散，熱によ る揮発，分解による消費が原因と考えられる。

Table 3 Concentration of additives in the immersion fluid treated for 1day

\begin{tabular}{cccc}
\hline additives & IPPD & S & $\mathrm{Zn}$ \\
\hline $\begin{array}{c}\text { Concentration in the } \\
\text { immersion fluid / ppm }\end{array}$ & 173 & 57 & 57 \\
\hline
\end{tabular}

\section{4. 結}

\section{論}

加硫ゴム用として一般的なアミン系老化防止剂である IPPD を配合したEPDMについて老化防止剤の分布とべー スポリマーの劣化状態の検討より

1 : 混練により均一に分散していたEPDM中のIPPDは 成型加工時の熱による分解あるいは, 表面からの揮散 により消費され, その結果, 表面近傍よりも内部によ り多く存在する傾向を示した.

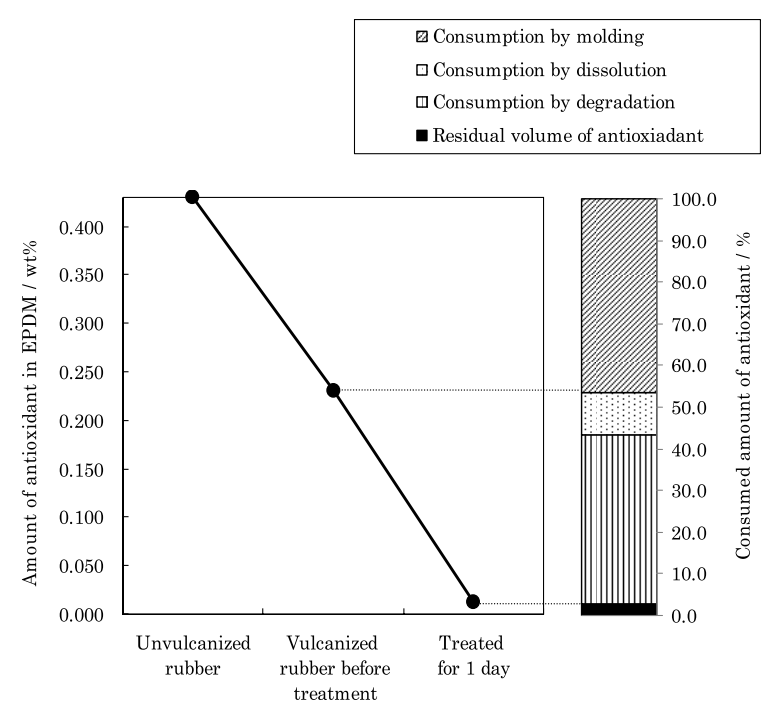

Figure 8 Amount of antioxidant in EPDM and consumed amount of antioxidant.

2 : 塩素水処理により IPPD はブルーム等の物理的現象 で表面から約 $200 \mu \mathrm{m}$ に多く存在するが，最表面の約 $50 \mu \mathrm{m}$ では残留塩素を含む水の浸透と劣化が同時に 生じ, IPPDは溶出あるいは残留塩素や熱によるポリ マーの劣化で生成したラジカル捕捉が原因で消費され た。

3 : 老化防止剤を失った最表面では劣化が生じやすい状 態となり，加硫ゴム全体では十分に老化防止剂が残存 するにもかかわらず，表面荒れを伴う酸化劣化が進行 した。

以上の結論より加硫ゴム製品が水道水使用環境下にて長 期寿命を保つためには, 加硫ゴム表面に老化防止剂が効果 的に残存することが重要であり，そのためには適度なゴム との相溶性およびブルーム速度を有し, かつ水に対する溶 解度の低い老化防止剤の選択が有効であると考えられる.

\section{References}

1 ) Yamada, M.; Sugioka, Y.; Shin, H.; Amano, R.; Ohtake, Y.: Nippon Goти Kyoukaishi, 81, 44 (2008)

2 ) Nippon Gomu Kyokai: "Gomu Kougyou Binran (4th ed.)", Nippon Gomu Kyoukai, Tokyo, p.429 (1994)

3 ) Kawaguchi, Y.; Sumida, T.; Fukushima, Y.: Polyfile, 534, 68 (2008)

4 ) Nippon Gomu Kyokai: "Gomu Kougyou Binran (4th ed.)”, Nippon Gomu Kyoukai , Tokyo, p.434 (1994)

\section{日本語表記参考文献}

1 ）山田美緒, 杉岡佳彦, 進博人, 天野良三, 大武義人：日本ゴム 協会誌，81，44 (2008)

2 ）日本ゴム協会：ゴム工業便覧 (第四版), 日本ゴム協会, 東京, p.429 (1994)

3）川口洋平, 隅田憲武, 福嶋容子：Polyfile，534，68 (2008)

4）日本ゴム協会：ゴム工業便覧(第四版), 日本ゴム協会, 東京, p.433 (1994) 